\title{
PENGEMBANGAN GAME EDUKASI UNTUK MATERI BANGUN DATAR MENGGUNAKAN LINTASAN BELAJAR GEOMETRI
}

\author{
Clara Ika Sari Budhayanti ${ }^{1}$, Julius Bata ${ }^{2}$ \\ ${ }^{1}$ Program Studi Pendidikan Guru Sekolah Dasar, Universitas Katolik Indonesia Atma Jaya \\ Email: clara.ika@atmajaya.ac.id \\ ${ }^{2}$ Program Studi Sistem Informasi, Universitas Katolik Indonesia Atma Jaya \\ Email: julius.victor@atmajaya.ac.id
}

Masuk : 05-10-2020, revisi: 31-03-2021, diterima untuk diterbitkan : 06-04-2021

\begin{abstract}
Mathematics is an essential subject for students to master from the start. However, most students have difficulty learning mathematics and reduce interest in learning. This is one of the causes of low math test results. Therefore, a learning method or media was needed that can attract students' interest in learning. One of the learning media that can attract students' interest in educational games. This study aims to develop educational games that can be needed as a medium for learning mathematics, primarily material about geometry. The research method used in this research is development research. The geometry learning path is used as the basis for game design. The trial was conducted with a small group involving teachers and students. The game was developed using the Unity $3 D$ game engine with a digital storytelling model in the geometry learning pathway in elementary schools. The results of the development show that the educational game with the name "GEMBIRA" can help improve the ability to learn flat shapes. This game can also help the learning process of students who experience learning trajectories based on Piaget and Van Hiele's learning trajectories. The game "GEMBIRA" can also attract students' attention to complete all the games, so that students can gain complete knowledge and understanding of the concept of flat shapes. Teachers are advised to use the game "GEMBIRA" in the learning process, especially learning material for flat shapes. It is suggested for learning media developers, especially educational game developers, to develop educational games by referring to the learning trajectory that students must pass so that the games developed can complement the learning process at school.
\end{abstract}

Keywords: Learning trajectory, educational game, geometry

\begin{abstract}
ABSTRAK
Matematika merupakan mata pelajaran yang penting untuk dikuasai oleh siswa sejak awal. Namun, sebagian besar siswa mengalami kesulitan belajar matematika dan mengurangi minat belajar. Hal ini menjadi salah satu penyebab hasil tes matematika cenderung rendah. Oleh karena itu, dibutuhkan cara atau media pembelajaran yang dapat menarik minat belajar dari siswa. Salah satu media pembelajaran yang dapat menarik minat siswa adalah game edukasi. Penelitian ini bertujuan untuk mengembangkan game edukasi yang dapat digunakan sebagai media pembelajaran matematika khususnya materi tentang geometri. Metode penelitian yang digunakan dalam penelitian ini adalah penelitian pengembangan. Lintasan belajar geometri digunakan sebagai dasar untuk merancang game. Uji coba dilakukan dengan small group yang melibatkan guru dan siswa. Game dikembangkan dengan menggunakan game engine Unity $3 D$ dengan model digital storytelling dalam lintasan belajar geometri di sekolah dasar. Hasil pengembangan menunjukkan bahwa game edukasi dengan nama "GEMBIRA" dapat membantu meningkatkan efektivitas pembelajaran bangun datar. Game ini juga dapat membantu proses belajar siswa yang mengalami lompatan tahapan pembelajaran berdasarkan lintasan belajar Piaget dan Van Hiele. Selain itu, game "GEMBIRA" juga dapat menarik perhatian siswa untuk menyelesaikan seluruh game, sehingga siswa dapat memperoleh pengetahuan dan pemahaman yang utuh mengenai konsep bangun datar. Guru disarankan untuk menggunakan game "GEMBIRA" dalam proses pembelajaran, khususnya pembelajaran materi bangun datar. Selain itu juga disarankan bagi para pengembang media pembelajaran khususnya pengembang game edukasi, untuk mengembangkan game-game edukasi dengan mengacu pada lintasan belajar yang harus dilalui siswa sehingga game yang dikembangkan dapat melengkapi kekurangan proses pembelajaran di sekolah.
\end{abstract}

Kata Kunci: Lintasan belajar, game edukasi, geometri 


\section{PENDAHULUAN}

Prestasi belajar matematika siswa SD di Indonesia masih jauh dibandingkan dengan siswa SD di negara-negara lain. Hasil penilaian yang dilakukan TIMSS (Trends in International Mathematics and Science Study) pada tahun 2015 menunjukkan bahwa siswa kelas IV SD di Indonesia menduduki posisi ke enam dari bawah dengan skor 397 dari 50 negara. Kemampuan siswa sangat rendah pada domain bilangan dan geometri yang hanya mencapai skor masing-masing 24 pada bilangan dan 28 pada geometri (Gronmo et al., 2015). Rendahnya hasil belajar matematika, khususnya dalam domain geometri ini seringkali diasosiasikan oleh berbagai pihak dengan proses pembelajaran geometri dan pengukuran yang bersifat rote learning, yaitu pembelajaran yang tidak memberi kesempatan bagi siswa untuk memahami hubungan berbagai konsep geometri sehingga memungkinkan siswa mencapai higher order thinking skills (HOTS), kecerdasan spasial dan kemampuan penalaran geometri (spatial thinking and geometric reasoning).

Terkait dengan hal tersebut, pembelajaran geometri di sekolah dasar seharusnya memberi kesempatan siswa untuk mengeksplorasi bagian serta sifat bangun datar dan bangun ruang. Selain itu, siswa juga dapat menghubungkan berbagai pengalaman visual dan spasial. Oleh karena itu, pembelajaran geometri dan pengukuran memerlukan media pembelajaran yang memungkinkan siswa dapat melakukan eksplorasi. Salah satunya adalah media pembelajaran interaktif berbasis teknologi. Media pembelajaran geometri interaktif berbasis teknologi memiliki berbagai kelebihan yang tidak dimiliki oleh media pembelajaran konvensional (Clements \& McMillen, 1996). Media pembelajaran terutama yang berbasis komputer lebih fleksibel, dapat merubah ukuran dan bentuk benda yang ditampilkan, dapat disimpan dengan mudah dan memungkinkan konfigurasi dinamis dari media tersebut. Selain itu, media pembelajaran berbasis komputer yang interaktif juga memungkinkan siswa untuk memahami perilaku belajar mereka karena mendapatkan umpan balik secara langsung.

Dari berbagai media pembelajaran geometri berbasis komputer, media pembelajaran dalam bentuk game edukasi adalah salah satu media pembelajaran yang dinilai paling sesuai untuk digunakan di sekolah dasar. Game edukasi dapat meningkatkan minat siswa untuk belajar matematika (Chang et al., 2015; McLaren et al., 2017). Berbagai game telah dikembangkan untuk pembelajaran matematika. Arifah et al. (2019) mengembangkan game edukasi yang memuat materi bilangan. Hasil pengujian terhadap siswa menunjukkan game edukasi menarik bagi siswa dan dapat meningkatkan hasil belajar. Pada penelitian lain, Animo Math dikembangkan untuk meningkatkan fokus siswa ketika belajar matematika (Sukstrienwong, 2018). Animo Math merupakan game berbasis peran (role-playing Game - RPG) untuk materi penjumlahan dan pengurangan bilangan. Game berbasis peran (RPG) dapat melatih daya imajinasi anak sehingga meningkatkan minat anak. Animo Math diuji kepada anak dengan pengawasan orang tua. Berdasarkan hasil evaluasi kepuasan pengguna, Animo Math mendapat tanggapan positif dari para orang tua. Beberapa hasil penelitian tersebut dapat menunjukkan manfaat dari game edukasi dalam pembelajaran matematika.

Pengembangan game edukasi dalam pembelajaran matematika masih sangat diperlukan terutama untuk materi geometri dan pengukuran. Salah satu contoh game untuk materi geometri adalah game yang dikembangkan oleh Wallner et al. (2018). Mereka mengembangkan game Lost My Way yang berfokus pada materi geometri khususnya transformasi. Pada game ini, siswa diberi tugas untuk mengembalikan domba yang tersesat ke kandangnya. Selama proses menyelesaikan tugas tersebut, siswa akan menyusun jalur yang dapat disesuaikan dengan menggunakan translasi, rotasi dan pencerminan. Selain Wallner et al. (2018), tidak banyak game edukasi untuk materi geometri dan pengukuran di sekolah dasar terutama di Indonesia. Oleh karena itu, upaya untuk 
mengembangkan game-game baru terkait materi geometri dan pengukuran di sekolah dasar masih sangat diperlukan. Penelitian ini bertujuan untuk mengembangkan game yang pada pembelajaran geometri khususnya mengenal berbagai bentuk bangun datar dan mengenal sifat-sifat bangun datar sederhana. Game akan dikembangkan dengan mengacu pada lintasan belajar yang menghasilkan tahapan-tahapan pembelajaran geometri. Tahapan pembelajaran menjadi penting dalam pembelajaran geometri, karena dengan adanya lintasan belajar geometri memungkinkan siswa untuk belajar geometri secara berkelanjutan. Selain itu, siswa juga dapat melihat hubungan antar konsep geometri dan belajar sesuai dengan tingkatan (level). Penelitian ini diharapkan bermanfaat bagi guru dan siswa untuk menggunakan game yang dikembangkan sebagai salah satu media pembelajaran di kelas maupun pembelajaran individu. Diharapkan juga penelitian ini bermanfaat sebagai acuan dalam mengembangkan game edukasi bagi pengembang media pembelajaran.

\section{METODE PENELITIAN}

Penelitian ini dilaksanakan dengan menggunakan metode penelitian dan pengembangan. Metode penelitian dan pengembangan atau research and development $(\mathrm{R} \& \mathrm{D})$ merupakan metode yang digunakan untuk melakukan penelitian dalam menghasilkan produk baru dan selanjutnya menguji keefektifan produk tersebut (Purnama, 2013). Penelitian ini dilaksanakan dengan mengacu pada tahapan penelitian Tessmer (1993) yang berfokus pada dua tahap, yaitu tahap preliminary dan tahap formative evaluation. Pada tahap preliminary, dilakukan penelitian awal untuk menggali kebutuhan subjek penelitian terkait dengan game yang akan dikembangkan. Sedangkan pada tahap formative evaluation, penelitian dilakukan melalui 3 subtahapan yaitu self-evaluation, prototyping, dan small group. Subtahapan self-evaluation bertujuan untuk mengevaluasi hasil analisis kebutuhan yang dilakukan di tahapan sebelumnya. Kemudian, ditindaklanjuti dengan analisis kurikulum dan analisis perangkat yang akan dikembangkan. Selanjutnya, berdasarkan hasil analisis dilakukan desain game edukasi yang akan dikembangkan.

Berdasarkan desain tersebut, disusun storyboard game sebagai prototype I. Game yang dikembangkan dalam penelitian ini merupakan game edukasi yang memiliki unsur cerita. Cerita dalam game ini tentang seorang anak yang tersesat ke dalam dunia antah berantah dan berjuang untuk kembali ke dunianya. Dari cerita ini, disusunlah alur permainan untuk seluruh game. Alur permainan dimulai dengan menampilkan cerita awal. Cerita awal berfungsi memberikan gambaran awal tentang seluruh permainan. Selain itu, cerita awal juga berfungsi menarik minat siswa untuk memainkan game. Terdapat menu utama yang terdiri dari menu "mulai" dan "petunjuk permainan".

Game edukasi terdiri dari sejumlah tantangan yang harus diselesaikan oleh pengguna. Setiap tantangan dilengkapi dengan petunjuk awal dan penjelasan setelah berhasil untuk menyelesaikan tantangan. Penjelasan diberikan kepada pengguna disesuaikan dengan kondisi apakah pengguna berhasil atau tidak dalam menyelesaikan tantangan. Selanjutnya, game akan selesai jika pengguna sudah berhasil menyelesaikan seluruh tantangan. Game diakhiri dengan cerita penutup. Alur permainan dapat dilihat pada gambar 1. 


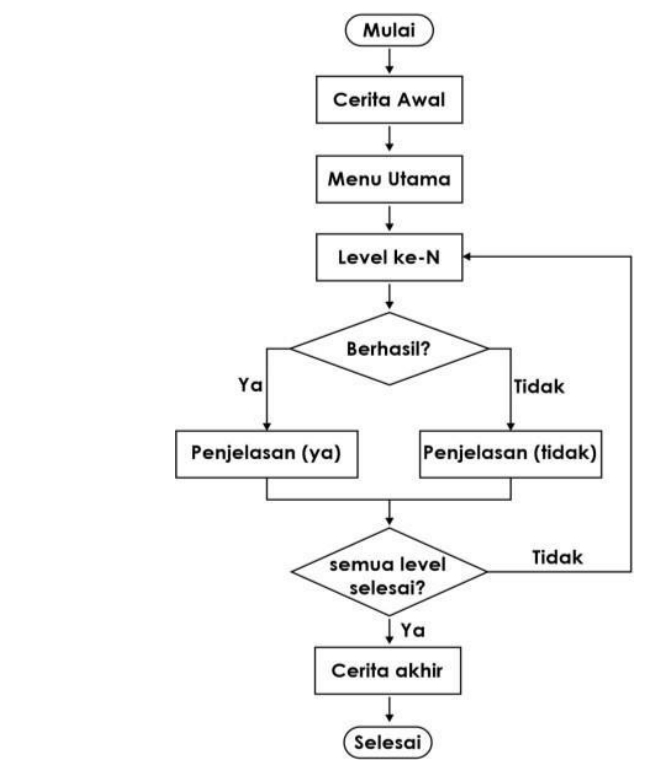

Gambar 1. Alur Permainan Game GEMBIRA

Pada tahap ini, desain game dalam bentuk storyboard disebut sebagai prototype pertama. Prototype pertama divalidasi dengan teknik triangulasi data yakni desain tersebut divalidasi oleh pakar (expert) dan teman sejawat. Ahli yang melakukan validasi merupakan ahli materi dan media. Prototype pertama yang sudah valid digunakan sebagai dasar membuat game edukasi. Game edukasi yang telah dibuat disebut prototype kedua, yang kembali diberikan pada pakar (expert review) untuk divalidasi. Game divalidasi oleh ahli materi, ahli media, dan ahli bahasa. Selain divalidasi oleh ketiga ahli, prototype kedua juga diberikan kepada guru sebagai ahli pembelajaran. Hasil review, nilai dan evaluasi dari pakar/ahli digunakan untuk merevisi perangkat yang dikembangkan (prototype ketiga). Prototype ketiga diujicobakan pada small group, terdiri dari lima grup kelas yang masing-masing grup memuat 5-10 siswa. Siswa diminta untuk memainkan game yang telah dikembangkan dan memberikan masukan terkait game tersebut.

\section{HASIL DAN PEMBAHASAN}

Penelitian ini menghasilkan game edukasi untuk pembelajaran matematika khususnya tentang bangun datar. Game edukasi dengan nama "GEMBIRA", dikembangkan berdasarkan hasil analisis kebutuhan yang dilakukan dengan menyebarkan kuesioner kepada delapan guru di sekolah. Data hasil kuesioner menunjukkan bahwa guru menganggap bahwa pembelajaran matematika perlu menggunakan media untuk membantu siswa memahami materi. Media pembelajaran matematika yang diperlukan adalah media pembelajaran yang berbasis ICT, yaitu media interaktif. Namun, meskipun guru-guru menyatakan bahwa pembelajaran matematika memerlukan media interaktif, tidak semua guru menggunakan media tersebut. Penggunaan media interaktif yang digunakan hanya berbentuk CD pembelajaran. Guru lebih sering menggunakan Lembar Kerja Siswa (LKS) dalam membantu siswa menguasai materi pelajaran matematika. Hasil analisis kebutuhan juga menunjukkan bahwa guru tidak menggunakan media interaktif karena keterbatasan dalam penggunaan media interaktif khususnya game. Guru juga belum pernah mengembangkan media interaktif sendiri, karena kesulitan dalam mengungkapkan ide serta pemahaman materi yang akan dibuat media interaktif. Selain itu, guru juga memiliki keterbatasan waktu dalam pembuatannya.

Di samping melakukan analisis kebutuhan, peneliti juga melakukan analisis siswa, analisis kurikulum, dan analisis perangkat yang dikembangkan dalam subtahapan self-evaluation. Analisis siswa dilakukan dengan teknik angket menggunakan kuesioner yang harus diisi oleh siswa kelas IV SD. Berdasarkan hasil angket, diketahui bahwa siswa-siswa tersebut pernah belajar matematika 
menggunakan media interaktif di kelas. Media interaktif yang digunakan berfungsi sebagai latihan. Selain itu, hanya beberapa siswa yang pernah menggunakan media interaktif dengan jenis permainan saat belajar matematika. Pada dasarnya, kebanyakan siswa menyatakan bahwa mereka lebih suka memilih belajar menggunakan media yang jenisnya permainan atau game. Siswa berharap sambil bermain game, mereka memperoleh penjelasan materi baik melalui proses bermain maupun melalui gambar atau video yang ada di media.

Pengembangan game juga didasarkan pada hasil analisis kurikulum yang dilakukan bersama ahli pembelajaran matematika. Analisis kurikulum menghasilkan beberapa indikator pembelajaran yang menjadi acuan dalam mengembangkan game "GEMBIRA'. Indikator pembelajaran yang dirumuskan mengacu pada lintasan belajar Piaget dan Van Hiele, yaitu: (a) siswa mampu membedakan objek geometri yang merupakan bangun datar; (b) siswa mampu mengidentifikasikan bangun datar yang sesuai dengan penampakannya; (c) siswa mampu mengenal unsur-unsur bangun datar; (d) siswa mampu membentuk bangun datar sederhana berdasarkan sisi-sisinya; dan (e) siswa mampu membentuk bangun datar sederhana dari bangun datar yang lain.

Pada hasil analisis kurikulum ditemukan bahwa tidak semua indikator yang sudah dirumuskan sesuai dengan kompetensi dasar (KD) yang ada. Indikator yang tidak terakomodasi pada kurikulum 2013 adalah indikator keempat dan kelima. Hal ini menunjukkan bahwa pembelajaran geometri di sekolah dasar bisa jadi mengalami lompatan tahapan belajar sehingga siswa tidak terampil merepresentasikan konsep geometri yang dipelajari, khususnya pada materi bangun datar. Pengalaman peneliti sebagai pengajar, masih banyak siswa atau mahasiswa yang memahami sifatsifat bangun datar namun kurang terampil dalam melukiskan bangun datar berdasarkan ciricirinya. Temuan ini sesuai dengan hasil penelitian Jamilaturrohmah (2019), bahwa dari 27 siswa, 15 siswa berada pada tingkat visualisasi yang melakukan kesalahan dalam mengenali dan menggambar bidang datar sesuai dengan penampakannya. Penelitian tersebut juga menemukan bahwa dua siswa yang berada pada tingkat deduksi informal masih melakukan kesalahan dalam memahami hubungan antar bangun datar. Kesalahan pemahaman relasi antar bangun datar terjadi karena biasanya pembelajaran yang diberikan guru kurang memberikan variasi pengalaman belajar, salah satunya membentuk bangun datar berdasarkan bangun datar yang lain.

Game "GEMBIRA" dikembangkan dengan menggunakan perangkat lunak Unity $3 D$ versi 2018.3.5f1 (64-bit). Perangkat lunak ini berjalan pada sistem operasi Windows 10 (64 bit) sehingga membutuhkan spesifikasi perangkat lunak minimal untuk dapat berjalan dengan baik yaitu Processor: Core i5, Memory: 4 GB, dan Graphic Card: DX11. Selain Unity 3D, game dikembangkan dengan menggunakan Adobe Photoshop untuk pembuatan asset game dan Visual Code Studio untuk menulis kode program. Ketiga perangkat lunak ini dipilih berdasarkan analisis kebutuhan pengembangan game dan kemampuan peneliti dalam penggunaannya.

Game GEMBIRA terdiri dari satu jenis game pembuka, tiga jenis game inti, dan satu jenis game penutup. Pada setiap game inti, dikembangkan beberapa level kesulitan. Game ini juga menyisipkan video dan halaman teks materi untuk membantu siswa memahami materi yang dipelajari. Game pembuka bertujuan mengantarkan siswa memasuki dunia petualangan melalui kegiatan identifikasi bangun datar dari beberapa objek geometri yang diberikan (Indikator 1). 


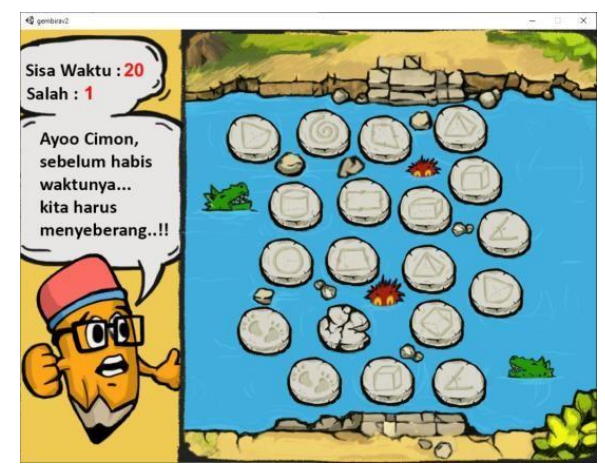

Gambar 2. Tampilan Game Pembuka

Pada game ini, siswa diminta membuat jalur penyeberangan berupa batu yang bergambar bangun datar. Semua siswa yang menjadi responden mampu menyelesaikan game pembuka ini. Beberapa siswa memerlukan beberapa kali percobaan. Namun, semua siswa yang mencoba game ini dapat menyelesaikannya sebelum batas waktu habis. Hal ini menunjukkan bahwa game pembuka memenuhi karakteristik game edukasi, yaitu active learning (Foreman, 2004). Menurut Foreman (2004), game harus memiliki kecenderungan untuk menyertakan pelajar secara aktif menciptakan penemuan dan pengetahuan baru yang membangun. Game pembuka yang dikembangkan ini dapat menjadi lingkungan yang membantu terjadinya penemuan baru siswa.

Pada game inti dikembangkan dua jenis game. Pada inti pertama, siswa diminta menembakkan peluru yang berbentuk sama dengan bentuk monster. Game ini bertujuan agar siswa mampu mengidentifikasikan bangun datar yang sesuai dengan penampakannya (Indikator 2).

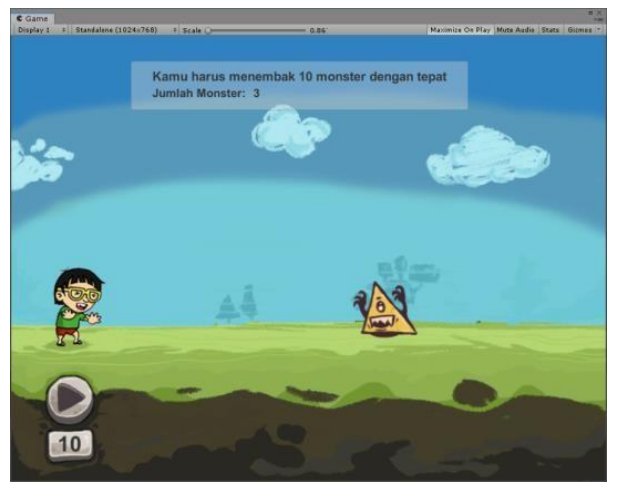

Gambar 3. Tampilan Game Inti Pertama

Game inti pertama terdiri dari beberapa level. Pada level terendah, monster yang muncul memiliki variasi bentuk yang tidak banyak. Sedangkan level tertinggi, dimunculkan bentuk monster yang lebih variatif sehingga mendorong pengguna untuk lebih teliti mengamati bentuk peluru sesuai bentuk monster yang muncul. Permainan dibuat lebih menantang dengan adanya batas waktu dan jumlah peluru yang dimiliki. Pada game ini, semua siswa mampu menyelesaikan game, baik siswa kelas IV dan V. Beberapa siswa kelas III membutuhkan waktu dua kali untuk menyelesaikan game ini karena kehabisan waktu. Hal ini menunjukkan bahwa siswa sudah memiliki pengalaman belajar mengenai bentuk-bentuk bangun datar. Apabila dilihat dari proses permainan, game ini dapat digunakan sebagai sarana pengembangan ketelitian dan kepekaan siswa terhadap bentuk-bentuk bangun datar. Kemampuan ini sangat jarang diperoleh dalam pembelajaran matematika di kelas. Biasanya, pembelajaran di kelas hanya berfokus pada penguasaan pengetahuan dan kurang mengembangkan keterampilan-keterampilan yang khas untuk menguasai matematika. Hal ini bertentangan dengan urgensi pembelajaran matematika di sekolah dasar yang dikemukakan oleh 
Cokrof (dalam Abdulrahman, 2003), bahwa pembelajaran matematika seharusnya dapat meningkatkan kemampuan berpikir logis, ketelitian, dan kesadaran keruangan.

Selanjutnya pada game inti kedua, terdiri dari tiga level permainan yang merepresentasikan indikator ketiga, yaitu mengenal unsur-unsur bangun datar. Pada level pertama, siswa diminta menaklukkan monster bangun datar dengan cara menekan titik kelemahan monster. Titik kelemahan monster merupakan titik sudut dari bentuk bangun datar monster. Sedangkan pada level kedua, siswa diminta untuk mengurung monster dengan cara membuat kandang yang bentuknya sesuai dengan bentuk monster bangun datar.

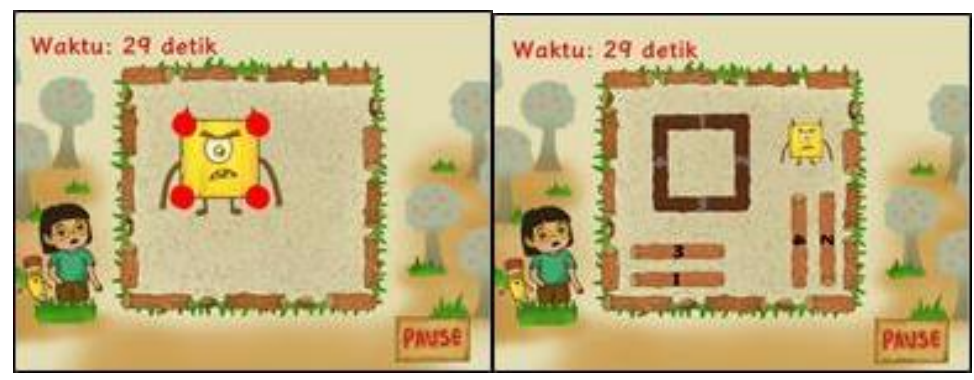

Gambar 4. Tampilan Game Inti Kedua level 1 dan 2

Pada level kedua, selain mengajarkan unsur bangun datar yang berupa sisi, game ini juga secara tidak langsung mengajarkan relasi antar garis yaitu garis sejajar dan tegak lurus. Dengan demikian, melalui game ini, siswa juga memperoleh pengalaman belajar untuk mengaitkan materi yang satu dengan yang lain sehingga pembelajaran menjadi bermakna bagi siswa. Sesuai dengan teori Ausubel yang menyatakan bahwa pembelajaran bermakna merupakan suatu proses mengaitkan informasi baru pada konsep-konsep relevan yang terdapat dalam struktur kognitif seseorang (Baharuddin \& Esa, 2010). Selanjutnya pada level ketiga, pengguna harus mengalahkan 10 monster bangun datar dengan cara memasukkan jumlah titik sudut dan sisi monster bangun datar dengan menekan tombol yang bergambar bom (representasi dari titik sudut) dan dinamit (representasi dari sisi bangun datar).

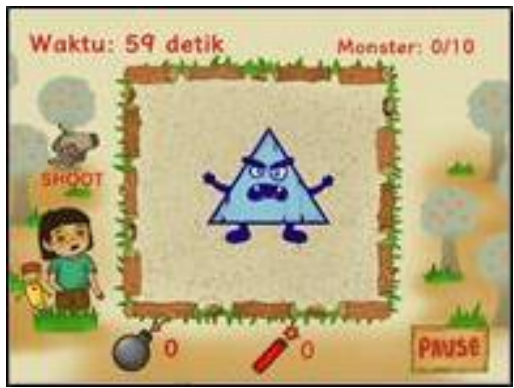

Gambar 5. Tampilan Game Inti Kedua level 3

Apabila diperhatikan, gambar yang melingkupi monster berbentuk persegi yang disusun dari balok-balok kayu. Gambar sengaja didesain seperti itu untuk mempersiapkan siswa belajar konsep baru mengenai keliling bangun datar khususnya persegi. Jika game ini digunakan dalam pembelajaran, maka bukan hanya dapat digunakan sebagai media pembelajaran materi konsep bangun datar, tetapi juga dapat digunakan sebagai media apersepsi untuk mempelajari materi keliling bangun datar bagi siswa. Pemanfaatan game dengan cara demikian, sesuai dengan hakikat matematika yang merupakan ilmu terstruktur dan terorganisasikan. Konsep-konsep matematika tersusun secara hierarkis, terstruktur, logis, dan sistematis, mulai dari konsep yang paling sederhana sampai konsep yang paling kompleks (Ibrahim \& Suparni, 2012). 
Pada game inti yang ketiga, siswa diminta memperhatikan video cara melipat kertas yang berbentuk persegi panjang menjadi bentuk bangun datar lain. Game ini bertujuan untuk membantu siswa memiliki kemampuan membentuk bangun datar sederhana berdasarkan sisi-sisinya (Indikator 4). Selesai melihat video, siswa akan diminta untuk menebak bentuk bangun datar berdasarkan petunjuk yang diberikan. Keterbatasan peneliti dalam mengeksplor aplikasi Unity 3D membuat game ini belum dapat dibuat pada saat penelitian. Oleh karena itu, saat uji coba dengan siswa dalam sesi game ini, penggunaan media pembelajaran ini dikombinasikan dengan aktivitas nyata, yaitu meminta siswa mendemonstrasikan cara melipat kertas untuk membentuk bangun datar lain sesuai dengan petunjuk yang diberikan guru. Pada sesi ini, hampir semua siswa kesulitan untuk mengubah kertas berbentuk persegi panjang menjadi bentuk bangun datar lain. Hal ini menunjukkan bahwa siswa kesulitan menghubungkan konsep antar bangun datar. Apabila situasi ini tidak segera diatasi, kesulitan dapat terus dibawa hingga ke jenjang pendidikan selanjutnya. Seperti hasil penelitian yang dilakukan oleh Toneng (2015), bahwa 94,43\% siswa SMP yang menjadi responden penelitian mengalami kesulitan dalam memvisualisasikan bangun segiempat. Temuan penelitian ini membuktikan asumsi peneliti terkait dengan hasil analisis kurikulum, bahwa siswa sekolah dasar mengalami lompatan belajar pada materi bangun datar.

Game edukasi GEMBIRA diakhiri dengan game penutup yang bertujuan untuk membantu siswa mengeksplor kemampuan membentuk bangun datar sederhana dari bangun datar yang lain (Indikator 5). Pada game ini, disajikan permainan dengan konsep Tangram di mana siswa diminta untuk memindahkan beberapa bentuk bangun datar pada pola yang diberikan.

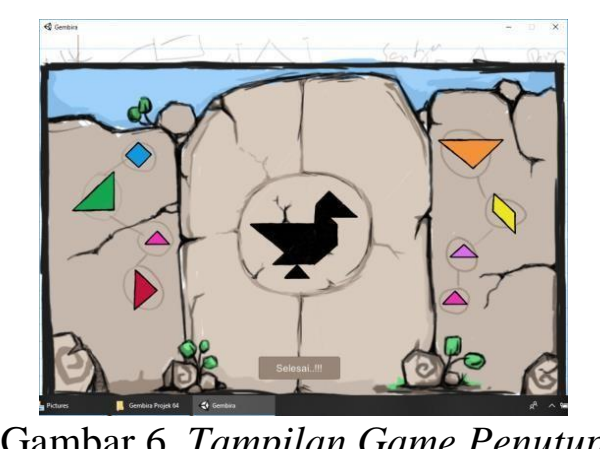

Gambar 6. Tampilan Game Penutup

Game ini membantu siswa bukan hanya memahami karakteristik bangun datar dari penampakannya dan unsur-unsurnya saja, namun juga mengembangkan kemampuan memahami secara mendalam karakteristik bangun datar yang diposisikan secara berbeda. Kemampuan pemahaman karakteristik bangun datar secara mendalam sangat dibutuhkan siswa agar tidak terjadi miskonsepsi yang berkelanjutan. Hasil penelitian yang dilakukan oleh Farida (2016) menunjukkan bahwa siswa sering menganggap persegi panjang hanya dalam posisi "biasa", yaitu dengan sisi mendatar (dalam arah pandang pembaca) adalah sisi terpanjang. Lebih lanjut lagi, Farida (2016) menjelaskan bahwa siswa mengalami miskonsepsi terhadap istilah segiempat karena tidak memahami hubungan antar segiempat, sifat-sifatnya, serta masih terpengaruh kebiasaan melukis bangun segiempat yang bersifat monoton (seperti yang dicontohkan guru atau buku pelajaran).

Secara umum, game yang dihasilkan dalam penelitian ini mendapat respon positif, baik dari guru maupun siswa. Guru mengungkapkan bahwa game ini akan sangat membantu siswa dalam belajar khususnya bagi siswa kelas kecil. Pendapat guru ini sesuai dengan hasil analisis kurikulum di mana kompetensi dasar pengenalan konsep bangun datar pada kurikulum 2013 ditemukan di kelas rendah yaitu kelas I sampai dengan III sekolah dasar. Temuan ini dapat menjadi evaluasi 
perubahan kurikulum pembelajaran matematika, karena sistem pembelajaran yang demikian ternyata tidak cukup membekali siswa untuk memahami konsep bangun datar secara mendalam. Oleh karena itu, siswa masih kesulitan untuk mempelajari konsep-konsep lain terkait dengan bangun datar. Pemahaman konsep bangun datar seharusnya diberikan secara kontinu sampai dengan kelas tinggi melalui berbagai pengalaman belajar sampai siswa memperoleh pengetahuan mengenai bangun datar secara utuh. Sementara itu, siswa mengungkapkan bahwa game edukasi GEMBIRA menarik dan sangat membantu siswa dalam memahami beberapa bentuk bangun datar. Bentuk-bentuk bangun datar dalam game sangat jelas dan mudah dibedakan satu dengan yang lain. Siswa semakin mudah memahami materi karena bahasa yang termuat dalam game sederhana, singkat, dan jelas serta disajikan dengan tampilan yang menarik.

Siswa tidak merasa kesulitan dalam penggunaan game karena petunjuk yang diberikan sangat jelas dan mudah dipahami. Game cukup menantang dan merangsang keingintahuan siswa untuk menyelesaikan game sampai selesai. Hal ini menunjukkan bahwa game edukasi GEMBIRA yang dikembangkan dapat meningkatkan efektivitas pembelajaran seperti yang diungkapkan oleh Sujalwo (2017), bahwa pembelajaran berbasis game merupakan salah satu cara yang efektif untuk meningkatkan motivasi belajar siswa, karena terdapat tantangan yang harus diselesaikan dalam game tersebut sehingga memunculkan rasa keingintahuan yang besar.

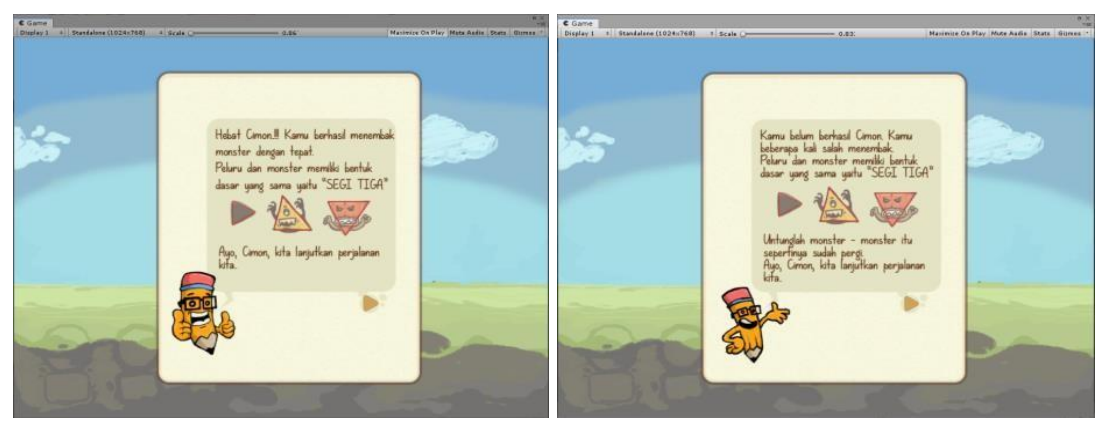

Gambar 7. Tampilan Review Materi

\section{KESIMPULAN DAN SARAN}

Penelitian ini menghasilkan game edukasi dengan nama GEMBIRA yang dapat membantu meningkatkan efektivitas pembelajaran bangun datar. Game ini juga dapat membantu proses belajar siswa yang mengalami lompatan tahapan pembelajaran berdasarkan lintasan belajar Piaget dan Van Hiele. Selain itu, game GEMBIRA juga dapat menarik perhatian siswa untuk menyelesaikan seluruh game, sehingga siswa memperoleh pengetahuan dan pemahaman yang utuh mengenai konsep bangun datar.

Berdasarkan hasil penelitian ini, direkomendasikan bagi guru untuk menggunakan game GEMBIRA dalam proses pembelajaran, khususnya pembelajaran materi bangun datar. Disarankan juga untuk para pengembang media pembelajaran, khususnya pengembang game edukasi, untuk mengembangkan game edukasi dengan mengacu pada lintasan belajar yang harus dilalui siswa. Hal ini bertujuan untuk melengkapi kekurangan proses pembelajaran di sekolah.

\section{Ucapan Terima Kasih (Acknowledgment)}

Ucapan terima kasih diberikan kepada Universitas Katolik Indonesia Atma Jaya yang telah mendukung dalam bentuk pendanaan melalui hibah penelitian kompetitif LPPM. Terima kasih kepada seluruh guru dan siswa yang telah bersedia untuk terlibat dalam proses pengujian dan saran untuk perbaikan game. 


\section{REFERENSI}

Abdurrahman, M. (2003). Pendidikan bagi anak berkesulitan belajar. Rineka Cipta. Arifah, REN. Baharuddin, \& Esa, N. W. (2010). Teori belajar dan pembelajaran. Penerbit Ar- Ruzz Media.

Chang, M., Evans, M. A., Kim, S., Norton, A., Deater-Deckard, K., \& Samur, Y. (2016). The effects of an educational video game on mathematical engagement. Educ. Inf. Technol., 21(5), 1283-1297.

Clement, D. H., \& McMillen, S. (1996). Rethinking concrete manipulatives. Teaching Children Mathematics, 2(5), 270 - 279.

Farida, A. (2016). Analisis miskonsepsi siswa terhadap simbol dan istilah matematika pada konsep hubungan bangun datar segiempat melalui permainan dengan alat peraga. Prosiding Konferensi Nasional Penelitian Matematika dan Pembelajarannya (KNPMP I) Universitas Muhammadiyah Surakarta

Foreman, J. G. (2004). Game-based learning: How to delight and instruct in the 12 st century. Educause Review.

Gronmo, L., S., Lindquist, M., Arora, A., Mullis, I. V. S. (2015). TIMSS 2015 mathematics framework. Timss, 11-27

Ibrahim, S., \& Suparni, M. P. (2012). Pembelajaran matematika teori dan aplikasinya. Suka- Press UIN Sunan Kalijaga.

Jamilaturrohmah, J., \& Rejeki, S. (2019). Analisis kesalahan dalam menyelesaikan soal materi bidang datar berdasarkan teori van hiele pada siswa kelas VIII SMP Negeri 2 Colomadu [Thesis, Universitas Muhammadiyah Surakarta].

McLaren, B. M., Adams, D. M., Mayer, R. E., \& Forlizzi, J. (2017). A computer-based game that promotes mathematics learning more than a conventional approach. International Journal of Game-Based Learning, 7(1), 36-56.

Purnama, S. (2013). Metode penelitian dan pengembangan (pengenalan untuk mengembangkan produk pembelajaran bahasa Arab). Jurnal LITERASI, 4(1). http://dx.doi.org/10.21927/literasi.2013.4(1).19-32

Tessmer, M. (1993). Planning and conducting-formative evaluations. Kogan Page.

Toneng, S. (2015). Kajian kesulitan belajar dari segi epistemologi siswa pada materi bangun datar segi empat di SMP. [Skripsi, Universitas Negeri Gorontalo].

Sujalwo, S. (2017). Pengembangan Game Berbasis Komputer Sebagai Media IPA Terpadu Kelas VII SMP.

Sukstrienwong, A. (2018). Animo math: The role-playing game in mathematical learning for children. TEM Journal, 7(1), 147-154.

Wallner, G. Kriglstein, D. Gabriel, S. Loh, CS. Sheng, Y. \& Li, IH. (2018). Lost my way: An educational geometry game for young children. Proceedings of the 13th International Conference on the Foundations of Digital Games, New York, 1-4. 